\title{
Synthesis, Crystal Structure, and Comparative Study of a New Organic Material 3,4-Diaminobenzophenone Semihydrate
}

\author{
Tarek Ben Rhaiem, Habib Boughzala, and Ahmed Driss \\ Laboratoire de Matériaux et Cristallochimie, Faculté des Sciences de Tunis, Université de Tunis El Manar, 2092 Tunis, Tunisia \\ Correspondence should be addressed to Habib Boughzala; habib.boughzala@ipein.rnu.tn
}

Received 22 May 2013; Accepted 15 July 2013

Academic Editor: Liviu Mitu

Copyright ( 2013 Tarek Ben Rhaiem et al. This is an open access article distributed under the Creative Commons Attribution License, which permits unrestricted use, distribution, and reproduction in any medium, provided the original work is properly cited.

The new organic 3,4-diaminobenzophenone semihydrate $(34 \mathrm{ABPH})$ is grown by slow evaporation method. The compound crystallizes in the monoclinic space group: C2. The unit cell dimensions are $a=28.703$ (8) $\AA$, $b=4.722(2) \AA, c=8.7076(10)$ $\AA$, and $\beta=99.40(2)^{\circ}$ with $Z=2$. The crystal structure analysis reveals that the $\mathrm{C}_{13} \mathrm{H}_{12} \mathrm{~N}_{2} \mathrm{O}$ molecules chains are organized into a double ribbon in the $(b, c)$ plane. The structural components interact by $\mathrm{N}-\mathrm{H} \cdots \mathrm{O}$ and $\mathrm{O}-\mathrm{H} \cdots \mathrm{O}$ hydrogen bonds, building up a two-dimensional network. The presence of functional groups in the molecular structure is confirmed by the Fourier transform infrared (FT-IR) spectroscopy. Thermogravimetric analysis (TGA) confirms the presence of the water molecule.

\section{Introduction}

During the crystallization process it is common that one or more solvent molecules are involved in the structure leading to pseudopolymorphic forms. Sometimes a single molecule can give up to 15 forms between polymorphic and pseudopolymorphic. These different forms are generated by the crystallization conditions (solvent, temperature...). This crystallization phenomenon is very important in the pharmaceutical industry because it directly affects the bioavailability of drugs. In our work we have synthesized and analyzed a new pseudopolymorphic in the diaminobenzophenones family. To go deeper in molecular polymorphism many papers can be found in the literature $[1,2]$.

The diamine compounds are important in biological active natural products [3-5] and in medicinal chemistry $[6,7]$. They are also used as auxiliaries and chiral ligands in asymmetric catalysis [8]. In this work, a new member of this family, $2 \mathrm{C}_{13} \mathrm{H}_{12} \mathrm{~N}_{2} \mathrm{O} \cdot \mathrm{H}_{2} \mathrm{O}$, is presented. Water is a highly versatile component at the interface of organic molecule. In fact, it can act both as a hydrogen bond donor and acceptor. Compared to other solvent molecules it imposes few steric constraints. It is able to establish hydrogen bond networks, occupying less space than the hydrophilic side chains of a protein. Therefore, we performed a brief comparative study between our compound and a similar anhydrous to show the role of the water molecule in the crystal cohesion.

\section{Experimental}

2.1. Synthesis of $(34 A B P H)$. The crystals of the compound were prepared by slow evaporation at room temperature by mixing 3,4-diaminobenzophenone $\mathrm{C}_{13} \mathrm{H}_{12} \mathrm{~N}_{2} \mathrm{O}(0.47 \mathrm{mmol})$ with a solution of manganese dibromide $\mathrm{MnBr}_{2}(0.23 \mathrm{mmol})$ in a mixture of ethanol and water $(3: 1 \mathrm{v} / \mathrm{v})$. Few weeks later, yellow crystals were obtained.

2.2. Investigation Techniques. The title compound was studied by various physicochemical methods: X-ray diffraction, DSC, TGA, and IR spectroscopy.

2.3. X-Ray Diffraction. A single crystal was selected using a polarizing microscope in order to perform X-ray diffraction analysis. Reflections intensities data were collected on an Enraf-Nonius CAD4 diffractometer [9] using graphite monochromated $\mathrm{MoK} \alpha$ radiation, $\lambda=0.71073 \AA$.

2.4. Computing Details. Program used to solve the structure is SHELXS97 [10], program used to refine the structure is SHELXL97 [10], structures projections were drawn with the 
TABle 1: Crystal data of $2 \mathrm{C}_{13} \mathrm{H}_{12} \mathrm{~N}_{2} \mathrm{O} \cdot \mathrm{H}_{2} \mathrm{O}$.

\begin{tabular}{lc}
\hline Empirical formula & $2 \mathrm{C}_{13} \mathrm{H}_{12} \mathrm{~N}_{2} \mathrm{O} \cdot \mathrm{H}_{2} \mathrm{O}$ \\
\hline Formula weight $\left(\mathrm{g} \cdot \mathrm{mol}^{-1}\right)$ & 442.51 \\
Crystal system & Monoclinic \\
Space group & $\mathrm{C} 2$ \\
$a$ & $28.703(8) \AA$ \\
$b$ & $4.722(2) \AA$ \\
$c$ & $8.7076(10) \AA$ \\
$\beta$ & $99.40(2)^{\circ}$ \\
$Z$ & 2 \\
Volume & $1164.3(6) \AA^{3}$ \\
$\rho_{\text {cal }}$ & $1.262 \mathrm{~g} \cdot \mathrm{cm}^{-3}$ \\
$F(000)$ & 468 \\
$\mu$ MoK $\alpha$ & $0.084 \mathrm{~mm}^{-1}$ \\
Crystal size & $0.16 \times 0.12 \mathrm{~mm}$ \\
Measured reflections & 1748 \\
Independent reflections & 1687 \\
$R_{\text {int }}$ & 0.0129 \\
Refined parameters & 202 \\
$R\left[F^{2}>2 \sigma\left(F^{2}\right)\right]$ & 0.050 \\
$w R\left(F^{2}\right)$ & 0.132 \\
Goodness of fit & 1.16 \\
\hline
\end{tabular}

DIAMOND program version 3.0 [11]. Crystal data and experimental parameters used for the intensity data collection are summarized in Table 1.

2.5. Physical Measurements. The Fourier transform infrared (FT-IR) technique was carried out to confirm the presence of functional groups and to find their vibrational modes. The sample was mixed thoroughly with dried $\mathrm{KBr}$. The spectrum was recorded in the range of 400 to $4000 \mathrm{~cm}^{-1}$ using a Bruker Vector 22 FT-IR spectrometer. The TG curve was recorded on a balance UGINE EYRAUD type B 60 . DSC from SETARAM instrumentations can provide further information about phase changes and reactions occurring at elevated temperatures.

\section{Results and Discussion}

3.1. Crystal Structure. In accordance with the single crystal $\mathrm{X}$-ray study, the title compound crystallizes as a monohydrate (Figure 1). The molecule is twisted with a dihedral angle of $54.1(2)^{\circ}$ between the 3,4-diaminophenyl and phenyl rings. Bond lengths and angles in the phenyl cycle are within the normal ranges and comparable with those found in homologous diaminobenzophenone [12]. Due to the 2-fold axis passing through the $\mathrm{H}_{2} \mathrm{O}$ position in the [010] direction, the asymmetric part of the unit cell consists of a $\mathrm{C}_{13} \mathrm{H}_{12} \mathrm{~N}_{2} \mathrm{O}$ molecule and a half water molecule. The nitrogen atoms of the amine groups are in a trigonal pyramidal configuration (sum of valence angles is $354.1^{\circ}$ for $\mathrm{N} 1$ and $328^{\circ}$ for N2) and deviate from phenyl plane, respectively, by-0.076 (4) A and 0.0041 (2) $\AA$. Conjugation between the nitrogen unshared electron pair and the $\pi$ system of the phenyl fragment leads to a shortening
TABLE 2: Hydrogen bond geometry $\left(\AA,^{\circ}\right)$.

\begin{tabular}{|c|c|c|c|c|}
\hline $\mathrm{D}-\mathrm{H} \cdots \mathrm{A}$ & $\mathrm{D}-\mathrm{H}$ & $\mathrm{H} \cdots \mathrm{A}$ & $\mathrm{D} \cdots \mathrm{A}$ & $\mathrm{D}-\mathrm{H} \cdots \mathrm{A}$ \\
\hline $\mathrm{N} 1-\mathrm{H} 1 \mathrm{~B} \cdots \mathrm{O} 1^{\mathrm{i}}$ & $0.96(4)$ & $2.10(4)$ & $2.956(4)$ & $148(3)$ \\
\hline $\mathrm{O} 2-\mathrm{H} 11 \cdots \mathrm{O} 1$ & $0.91(4)$ & $2.03(4)$ & $2.884(3)$ & $153(5)$ \\
\hline N1-H1A $\cdots$ N2 & $0.88(3)$ & $2.43(3)$ & $2.772(5)$ & $104(1)$ \\
\hline $\mathrm{N} 1-\mathrm{H} 1 \mathrm{~A} \cdots \mathrm{N} 2^{\mathrm{ii}}$ & $0.88(3)$ & $2.25(3)$ & $3.100(5)$ & $163(3)$ \\
\hline $\mathrm{N} 2-\mathrm{H} 2 \mathrm{~A} \cdots \mathrm{O} 2^{\mathrm{iii}}$ & $0.91(4)$ & $2.28(4)$ & $3.162(3)$ & $163(4)$ \\
\hline
\end{tabular}

Symmetry codes: (i) $x, y, z-1$; (ii) $-x, y,-z-1$; (iii) $x, y+1, z$.

of the N1-C11 bond (1.384 (3) $\AA$ ) and N2-C12 bond (1.402 (4) $\AA$ ) relatively to the standard length of a purely single N-Csp2 bond $(1.43-1.45 \AA)[13,14]$. On the other hand, the C1-C2 bond (1.480 (4) $\AA$ ) is longer than its neighbour C1-C8 (1.476 (4) $\AA$ ). This is probably due to the electron delocalisation at the $\mathrm{C} 8$ side of the molecule (Figure 1).

The crystal structure analysis reveals that the $\mathrm{C}_{13} \mathrm{H}_{12} \mathrm{~N}_{2} \mathrm{O}$ molecules chains are organized into a double ribbon in the $(b, c)$ plane. These planes are connected in pairs by intermolecular hydrogen bonds $\mathrm{O} 2-\mathrm{H} 11 \cdots \mathrm{O} 1$ and N1H1A $\cdots N 2^{\text {ii }}$ (symmetry code: (ii) $-x, y,-z-1$ ) (see Figure 2 and Table 2).

Each water molecule is surrounded by four organic molecules $\mathrm{C}_{13} \mathrm{H}_{12} \mathrm{~N}_{2} \mathrm{O}$ and linked to the carboxyl group and the amine radical (Figure 3 ). The sequence of the organic entities $\mathrm{C}_{13} \mathrm{H}_{12} \mathrm{~N}_{2} \mathrm{O}$ and the water molecules is provided by hydrogen bonds $\mathrm{N}-\mathrm{H} \cdots \mathrm{O}$ and $\mathrm{O}-\mathrm{H} \cdots \mathrm{O}$. A twodimensional network ensures the cohesion and the structure stability.

Before making any structural comparison it is necessary to standardize the networks of the two structures. Simply make a change in the mark of the second orthorhombic structure $\mathrm{C}_{13} \mathrm{H}_{12} \mathrm{~N}_{2} \mathrm{O}$ (4,4'-diaminobenzophenone [12]).

Compared to the anhydrous form $\left(4,4^{\prime}\right.$-diaminobenzophenone [12]), the title compound structure exhibits several common properties (cell parameters range, absence of centrosymmetry, and structural arrangement). On the other hand, the addition of two water molecules per unit cell increases the volume cell of about $80 \AA^{3} .40 \AA^{3}$ would be the volume occupied by a single water molecule in this type of structural arrangement. Furthermore, the water molecule seems to be lowering the crystal symmetry and enhancing the crystal cohesion by increasing the hydrogen bonds density.

The alignment of the water molecules along (a) and (c) axes induces their expansion compared to those of the anhydrous structure $\{a: 24.306$ (2) to 28.703 (8) $\AA(18 \%)\}$ and $\{b: 8.1110(7)$ to $8.7076(10) \AA(7 \%)\}$. The title compound $b$ parameter narrowing is probably due to the molecules closeness in the network further to the presence of the hydrogen bonds around the water molecule (Table 3 ).

To learn more about the water role in the structure and as published earlier [15], the anhydrous 3,4-diaminobenzophenone exhibits powerful properties in the analysis of oligonucleotides by matrix-assisted laser desorption/ionization time-of-flight mass spectrometry. It will be interesting to know if the semihydrated form (the title compound) will have comparable behavior or not. Similar work is planned. 


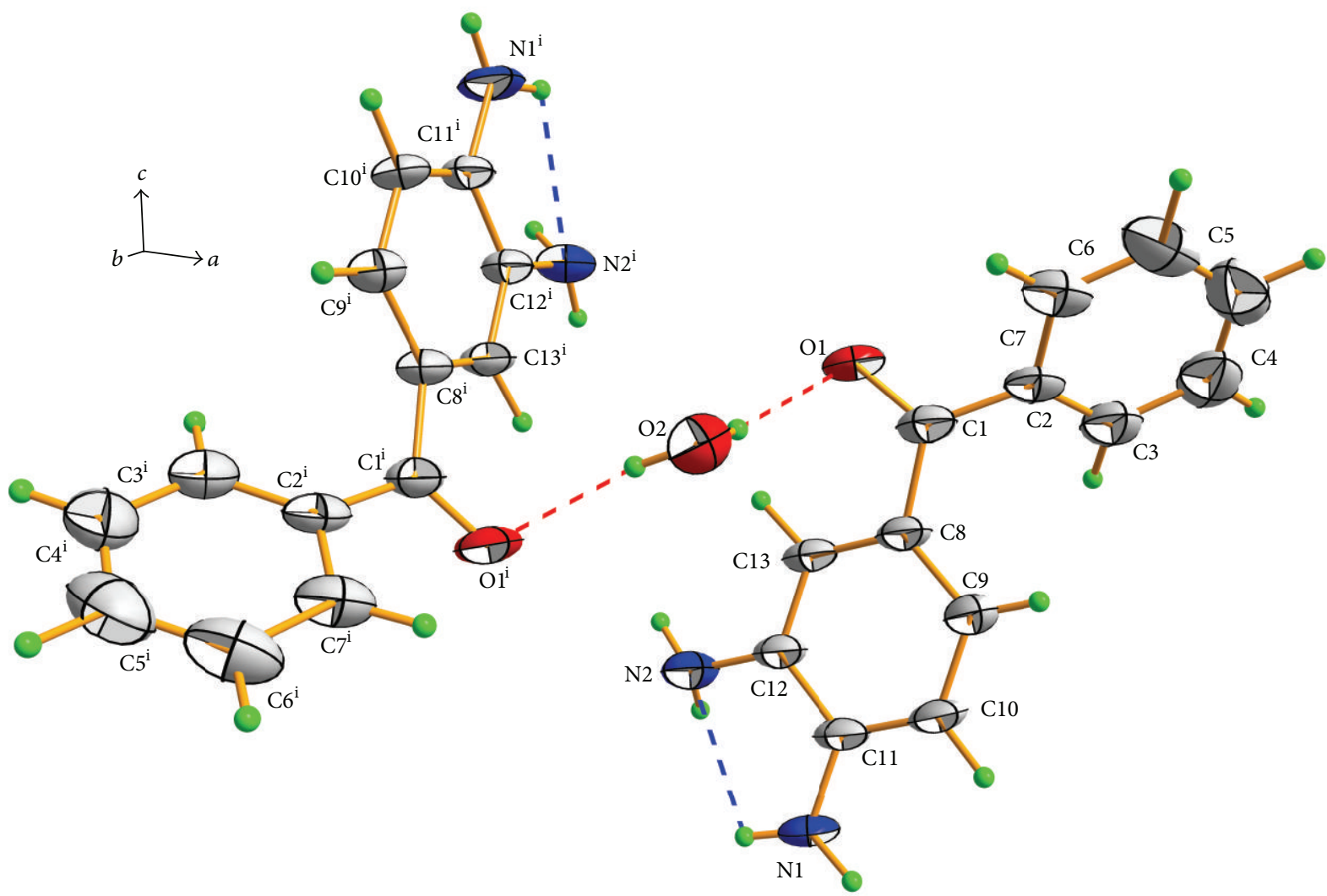

FIGURE 1: The molecular structure of the title compound, showing the atom numbering scheme. Displacement ellipsoids are drawn at the $50 \%$ probability level, and $\mathrm{H}$ atoms are shown as small spheres of arbitrary radii. Symmetry code: (i) $-x, y,-z$.

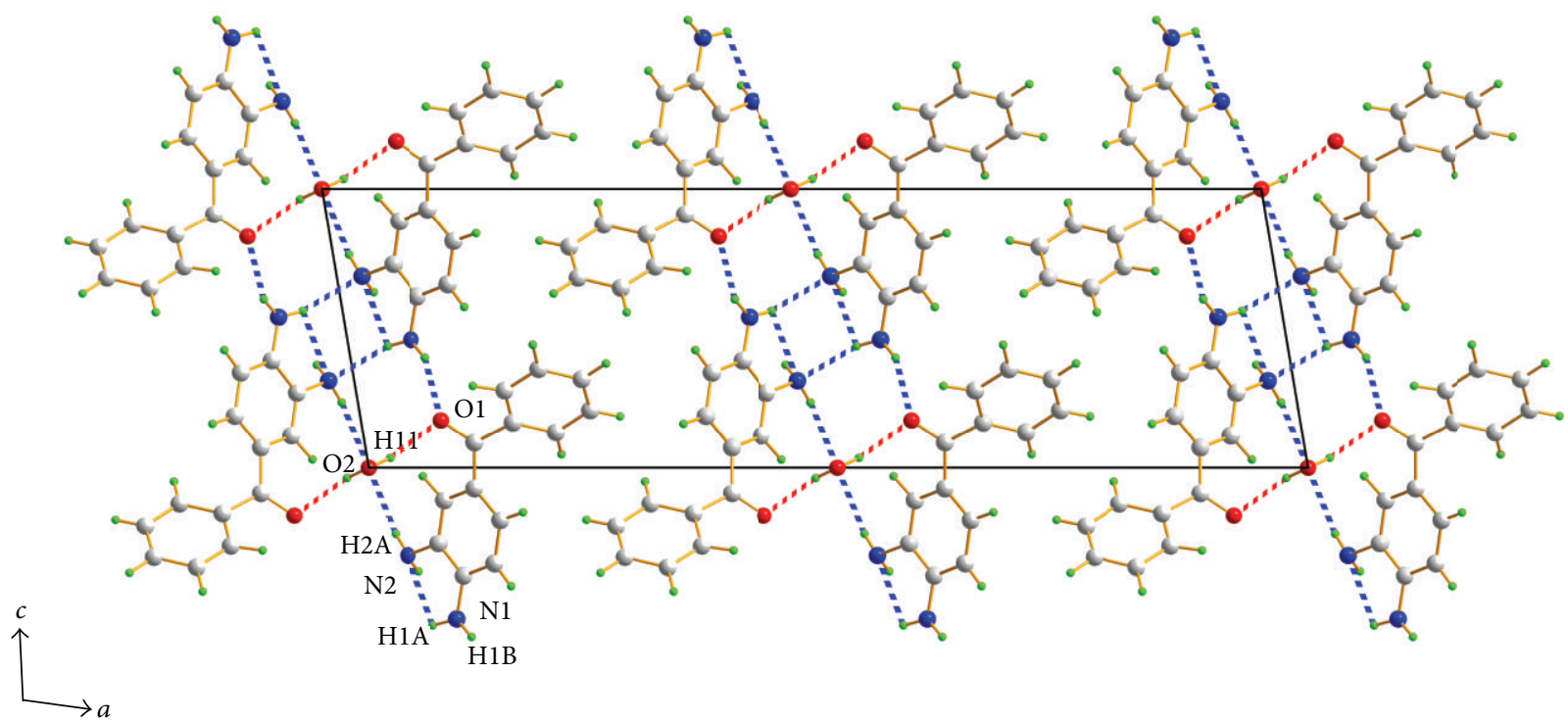

FIGURE 2: The crystal packing of the title compound, viewed along the $b$-axis showing the $\mathrm{N}-\mathrm{H} \cdots \mathrm{N} / \mathrm{O}$ and $\mathrm{O}-\mathrm{H} \cdots \mathrm{O}$ interaction $($ dotted lines).

3.2. IR Spectroscopy. The infrared (IR) spectroscopy is one of the major physical methods for investigating molecular structure. Figure 4 shows the recorded IR spectrum of the title compound.
Based on the previous literature results and the theoretical simulation of IR spectrum, the large band centred around $3600 \mathrm{~cm}^{-1}$ is attributed to the stretching modes of $\mathrm{O}-\mathrm{H}$ radicals. The bands located at $3380 \mathrm{~cm}^{-1}$ and $3190 \mathrm{~cm}^{-1}$ might 


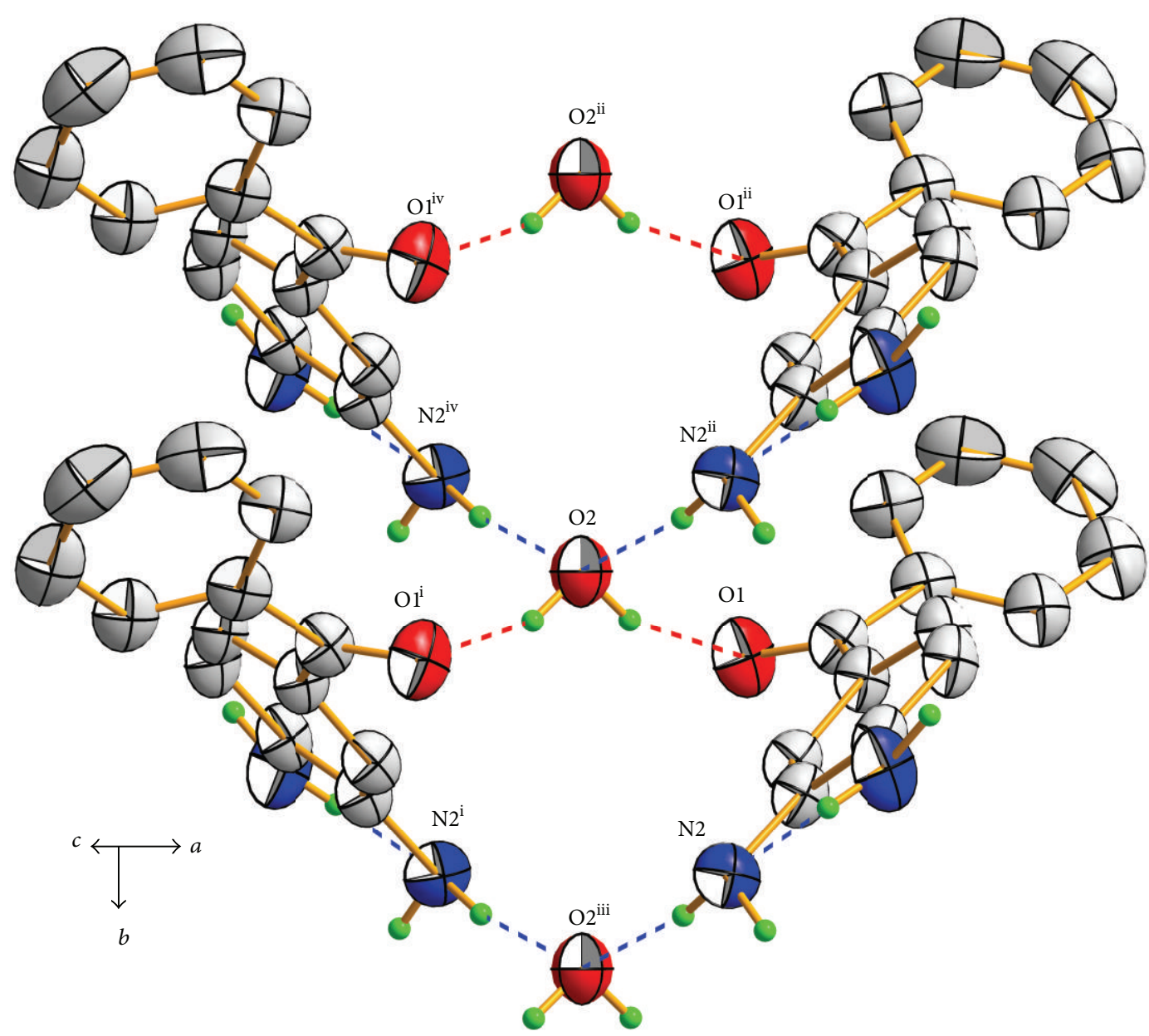

FIGURE 3: The role of water in the packing stabilization. $\mathrm{H}$ atoms not involved in hydrogen bonding (dashed lines) have been omitted for clarity. Displacement ellipsoids are drawn at $50 \%$ probability level. Symmetry codes: (i) $-x, y,-z$; (ii) $x, y-1, z$; (iii) $x, y+1, z$; (iv) $-x, y-1$, $-z$.

TABLE 3: The crystallographic parameters of $\mathrm{C}_{13} \mathrm{H}_{12} \mathrm{~N}_{2} \mathrm{O}$ and $2 \mathrm{C}_{13} \mathrm{H}_{12} \mathrm{~N}_{2} \mathrm{O} \cdot \mathrm{H}_{2} \mathrm{O}$.

\begin{tabular}{lccc}
\hline Compound & $\mathrm{C}_{13} \mathrm{H}_{12} \mathrm{~N}_{2} \mathrm{O}$ & $\mathrm{C}_{13} \mathrm{H}_{12} \mathrm{~N}_{2} \mathrm{O}$ & $2 \mathrm{C}_{13} \mathrm{H}_{12} \mathrm{~N}_{2} \mathrm{O} \cdot \mathrm{H}_{2} \mathrm{O}$ \\
\hline $\begin{array}{l}\text { Space group } \\
\text { Crystal }\end{array}$ & $\mathrm{P} 22_{1} 2_{1}$ & $\mathrm{P} 22_{1} 2_{1}$ & $\mathrm{C} 2$ \\
system & Orthorhombic & Orthorhombic & Monoclinic \\
$a(\AA)$ & $5,4982(5)$ & $24,306(2)$ & $28,703(8)$ \\
$b(\AA)$ & $8,1110(7)$ & $5,4982(5)$ & $4,722(2)$ \\
$c(\AA)$ & $24,306(2)$ & $8,1110(7)$ & $8,7076(10)$ \\
$\alpha\left(^{\circ}\right)$ & 90 & 90 & 90 \\
$\beta\left(^{\circ}\right)$ & 90 & 90 & $99,40(2)$ \\
$\gamma\left(^{\circ}\right)$ & 90 & 90 & 90 \\
$V\left(\AA^{3}\right)$ & $1083,95(16)$ & $1083,95(16)$ & $1164,3(6)$ \\
$Z$ & 4 & 4 & 2 \\
\hline
\end{tabular}

be assigned to the asymmetric and symmetric stretching modes of $\mathrm{N}-\mathrm{H}$ in the amine group, and the out-of-plane bending mode of this group is probably responsible for the

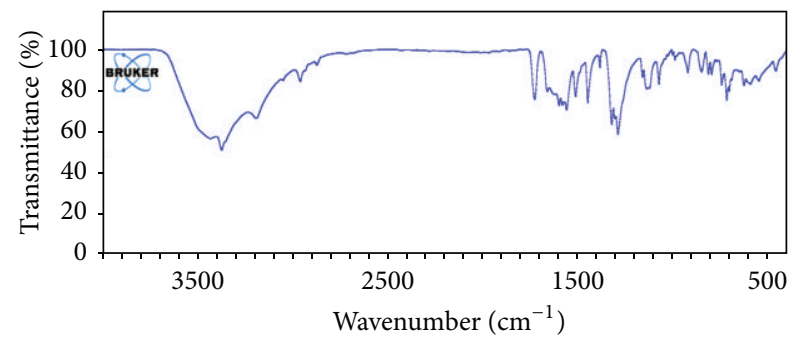

FIgURE 4: Experimental IR spectrum of compound $2 \mathrm{C}_{13} \mathrm{H}_{12} \mathrm{~N}_{2} \mathrm{O} \cdot \mathrm{H}_{2} \mathrm{O}$.

band at $1447 \mathrm{~cm}^{-1}$. The bands centred at $3000 \mathrm{~cm}^{-1}$ could be attributed to the stretching vibration of the $=\mathrm{C}-\mathrm{H}$ bonds in the aromatic group. The typical stretching band of carboxyl group $(>\mathrm{C}=\mathrm{O})$ is shown at $1728 \mathrm{~cm}^{-1}$. However, the range of bands between 1550 and $1700 \mathrm{~cm}^{-1}$ is attributed to the stretching vibration of the aromatic group $(\mathrm{C}=\mathrm{C})$. Finally, the bands between 500 and $1150 \mathrm{~cm}^{-1}$ are probably the result of the bending vibration of the $(=\mathrm{C}-\mathrm{H})$ and $\left(\mathrm{NH}_{2}\right)$ groups. 




FIGURE 5: Calculated IR spectrum of compound $2 \mathrm{C}_{13} \mathrm{H}_{12} \mathrm{~N}_{2} \mathrm{O} \cdot \mathrm{H}_{2} \mathrm{O}$.

TABLE 4: Calculated and experimental IR bands.

\begin{tabular}{lcc}
\hline $\begin{array}{l}\text { Calculated } \\
\text { frequencies } \\
\left(\mathrm{cm}^{-1}\right)\end{array}$ & $\begin{array}{c}\text { Experimental } \\
\text { frequencies } \\
\left(\mathrm{cm}^{-1}\right)\end{array}$ & Attribution \\
\hline 3991 & 3600 & Stretching $(\mathrm{O}-\mathrm{H})$ \\
3862 & 3380 & Stretching $(\mathrm{N}-\mathrm{H})$ \\
3520 & 3190 & Stretching $(\mathrm{C}-\mathrm{H})$ \\
3392 & 3000 & Stretching $(\mathrm{C}=\mathrm{O})$ \\
3058 & 1728 & Stretching $(\mathrm{C}=\mathrm{C})$ \\
1945 & $1550-1700$ & Bending $(\mathrm{O}-\mathrm{H})$ \\
1790 & 1512 & Bending $(\mathrm{N}-\mathrm{H})$ \\
1748 & 1447 & Stretching $(\mathrm{C}=\mathrm{C}),(\mathrm{C}-\mathrm{N})$ \\
1688 & $1200-1330$ & Bending $(\mathrm{C}-\mathrm{H}),(\mathrm{N}-\mathrm{H})$ \\
$1242-1628$ & $500-1150$ & \\
$500-1150$ & &
\end{tabular}

3.3. Theoretical IR Spectroscopy. The semiempirical parameterized model number 3 (PM3) treatment used by "CAChe" [16] program allows the IR vibrational frequencies calculations. On the other hand, the observed bands assignment becomes easier by comparing the observed frequencies and those calculated. Figure 5 shows the IR calculated spectrum after an optimisation of the molecular configuration. This model is very close to the obtained one by the structural investigations. The main observed vibrational bands are identified in the calculated one (see Table 4).

3.4. Morphology of (34ABPH). The crystal morphology is a key element in many industrial processes and has an enormous impact at the processing and postprocessing stages of pharmaceuticals, agrochemicals, petrochemicals, and cements. The morphology of crystalline solids influences their physical properties. Crystal morphology can alter the dissolution rate of chemicals and bioavailability of drugs and mechanical properties such as filtration, grinding, dusting and handling, and packaging and storage of crystalline products.

The Bravais-Friedel-Donnay-Harker (BFDH) laws [17, 18] are strictly based on the symmetry of the crystal lattice to generate an ordered list of possible growing faces. The view of the observed and calculated crystal morphologies reveals a

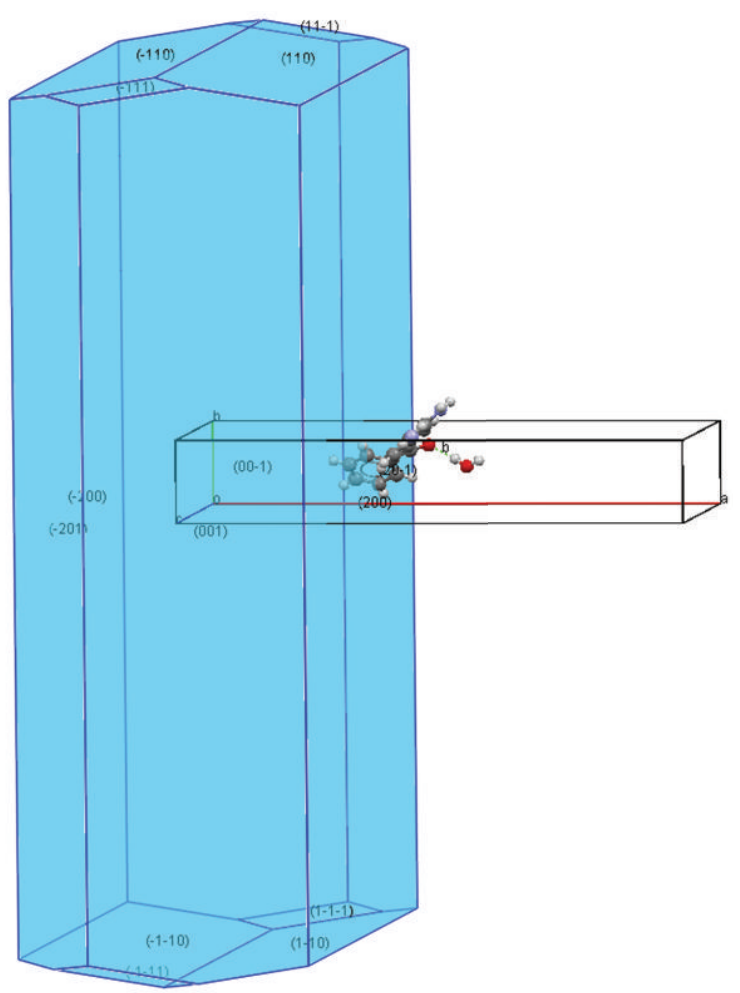

FIgure 6: Predicted morphology of $2 \mathrm{C}_{13} \mathrm{H}_{12} \mathrm{~N}_{2} \mathrm{O} \cdot \mathrm{H}_{2} \mathrm{O}$. Growth shape from BFDH rules.



FIGURE 7: Images of the growth morphologies of $2 \mathrm{C}_{13} \mathrm{H}_{12} \mathrm{~N}_{2} \mathrm{O} \cdot \mathrm{H}_{2} \mathrm{O}$.

similarity between the two shapes (see Figures 6 and 7). This examination is used to assign the crystal growth axe as the (001) and to identify the crystallographic axis and the physical ones.

3.5. Thermal and Calorimetric Analysis. Calorimetric and thermal studies were carried out to investigate the thermal behaviour of the studied phase. Both techniques were used 




Figure 8: DSC curve of $2 \mathrm{C}_{13} \mathrm{H}_{12} \mathrm{~N}_{2} \mathrm{O} \cdot \mathrm{H}_{2} \mathrm{O}$.



Figure 9: TG curve of $2 \mathrm{C}_{13} \mathrm{H}_{12} \mathrm{~N}_{2} \mathrm{O} \cdot \mathrm{H}_{2} \mathrm{O}$.

under controlled atmosphere and led to complimentarily results.

3.5.1. Differential Scanning Calorimetry. The DSC curve obtained in the temperature range of $\left[50^{\circ} \mathrm{C}, 350^{\circ} \mathrm{C}\right]$ and under nitrogen atmosphere reveals two endothermic phenomena (Figure 8). The first one happening at $80^{\circ} \mathrm{C}$ is due to the compound dehydration. The second one at $140^{\circ} \mathrm{C}$ is probably due to the departure of ammonia and carbon dioxide as shown by the TGA investigations.

3.5.2. Thermogravimetric Analysis. The thermogravimetric curve analysis of the title compound (Figure 9) was obtained with heating rate of $50^{\circ} \mathrm{C} \cdot \mathrm{h}^{-1}$, under argon atmosphere in temperature range $\left(25^{\circ} \mathrm{C}-300^{\circ} \mathrm{C}\right)$. It shows two mass losses. The first $[4.13 \% \pm 0.15 \%]$ happening at $80^{\circ} \mathrm{C}$ was attributed to the departure of the water molecule (theoretical value: $4.09 \%)$. The second mass loss $[31.05 \% \pm 0.27 \%]$ beginning around $140^{\circ} \mathrm{C}$ can be explained by the departure of four ammonia and two carbon monoxide molecules result of the product decomposition (theoretical value: $28.02 \%$ ).

\section{Conclusion}

We have synthesized in the present work a new organic compound $2 \mathrm{C}_{13} \mathrm{H}_{12} \mathrm{~N}_{2} \mathrm{O} \cdot \mathrm{H}_{2} \mathrm{O}$. A single crystal X-ray diffraction was carried out in order to solve the structure and to perform structural analysis. This compound has been characterized by IR vibrational spectroscopy. The semiempirical PM3 
treatment allows the IR vibrational frequencies calculations. The observed crystal morphology was compared to the simulated one obtained by the Bravais-Friedel, Donnay-Harker model. Calorimetric and thermal studies were carried out to investigate the thermal behaviour of the studied phase. Photoluminescence tests are planned to value this compound.

\section{References}

[1] I. M. R. Landre, F. T. Martins, J. A. Ellena, M. H. Dos Santos, and A. C. Doriguetto, "Pseudopolymorphism in hy-droxybenzo-phenones: the dihydrate of $2,2^{\prime}, 4,4^{\prime}$-tetra-hydroxybenzophenone," Acta Crystallographica C, vol. 68, no. 4, pp. o156-o159, 2012.

[2] I. M. R. Landre, T. E. Souza, R. S. Corrêa, F. T. Martins, and A. C. Doriguetto, "A monohydrate pseudopolymorph of 3,4-dihydroxybenzophenone and the role of water in the crystal assembly of benzophenones," Acta Crystallographica C, vol. 66, no. 9, pp. o463-o465, 2010.

[3] A. Pasini and F. Zunino, "New cisplatin analogues-on the way to better antitumor agents," Angewandte Chemie. International Edition, vol. 26, no. 7, pp. 615-624, 1987.

[4] M. Otsuka, T. Masuda, A. Haupt et al., "Man-designed bleomycin with altered sequence specificity in DNA cleavage," Journal of the American Chemical Society, vol. 112, no. 2, pp. 838845, 1990.

[5] D. Zaouali Zgolli, H. Boughzala, and A. Driss, "4-Sulfamoylanilinium chloride," Acta Crystallographica E, vol. 66, no. 6, p. o1488, 2010.

[6] E. T. Michalson and J. Szmuszkovicz, "Medicinal agents incorporating the 1,2-diamine functionality," Progress in Drug Research, vol. 33, pp. 135-149, 1989.

[7] J. Reedijk, "Improved understanding in platinum antitumour chemistry," Journal of the Chemical Society, Chemical Communications, no. 7, pp. 801-806, 1996.

[8] H.-U. Blaser, "The chiral pool as a source of enantioselective catalysts and auxiliaries," Chemical Reviews, vol. 92, no. 5, pp. 935-952, 1992.

[9] Enraf-Nonius, CAD-4 EXPRESS, Enraf-Nonius, Delft, The Netherlands, 1994.

[10] G. M. Sheldrick, "A short history of SHELX," Acta Crystallographica A, vol. 64, no. 1, pp. 112-122, 2007.

[11] K. Brandenburg, DIAMOND, Crystal Impact GbR, Bonn, Germany, 2006.

[12] Y.-H. Wen, Y.-H. He, Y.-L. Feng, and S. W. Ng, "An orthorhombic modification of 4,4' -diaminobenzophenone," Acta Crystallographica E, vol. 62, no. 5, pp. o1787-o1788, 2006.

[13] E. M. Burke-Laing and M. Laing, "Structures of nitrogencontaining aromatic compounds. III. Benzalazine, redetermination and refinement," Acta Crystallographica B, vol. 32, no. 12, pp. 3216-3224, 1976.

[14] F. H. Allen, O. Kennard, D. G. Watson, L. Brammer, A. G. Orpen, and R. Taylor, "Tables of bond lengths determined by $\mathrm{x}$-ray and neutron diffraction. Part 1 . Bond lengths in organic compounds," Journal of the Chemical Society, Perkin Transactions 2, no. 12, pp. S1-S19, 1987.

[15] Y. Fu, S. Xu, C. Pan, M. Ye, H. Zou, and B. Guo, "A matrix of 3,4diaminobenzophenone for the analysis of oligonucleotides by matrix-assisted laser desorption/ionization time-of-flight mass spectrometry," Nucleic Acids Research, vol. 34, no. 13, article e94, 2006.
[16] Cache: worksystem Pro Version 7.5.0.85, Fujitsu Limited. 20002006 Oxford Molecular.

[17] A. Bravais, Etudes Crystallographiques, Academie des Sciences, Paris, France, 2010.

[18] J. D. H. Donnay and D. Harker, "A new law of crystal morphology extending the Law of Bravais," American Mineralogist, vol. 22 , p. $463,1937$. 

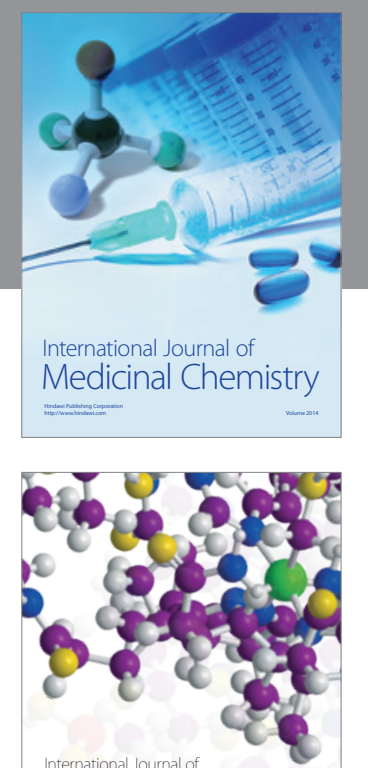

\section{Carbohydrate} Chemistry

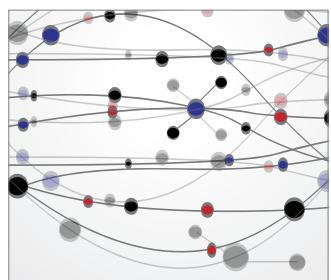

The Scientific World Journal

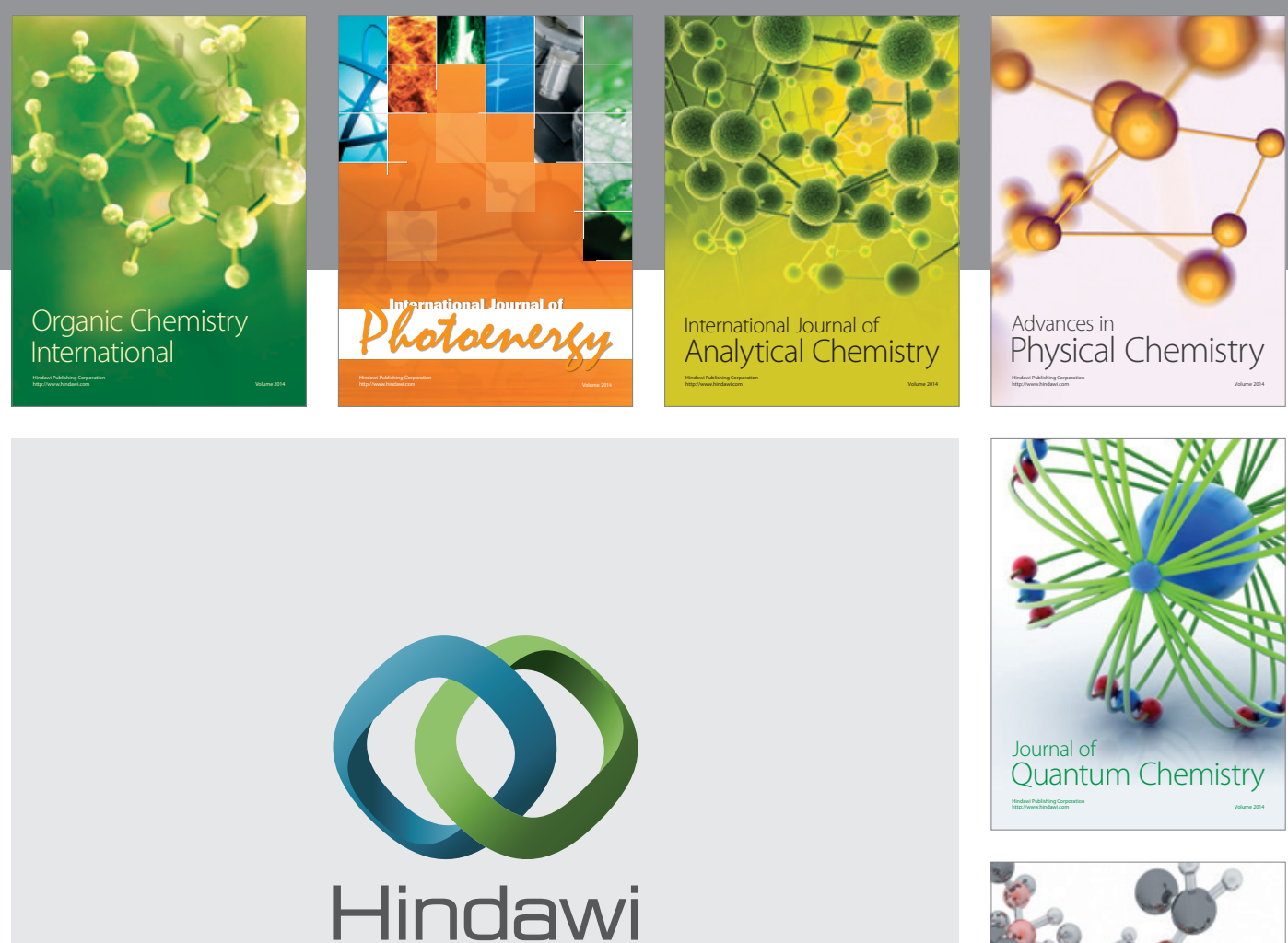

Submit your manuscripts at

http://www.hindawi.com



Analytical Methods

in Chemistry

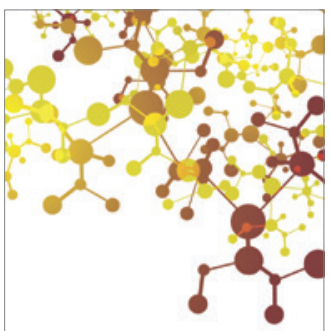

Journal of

Applied Chemistry

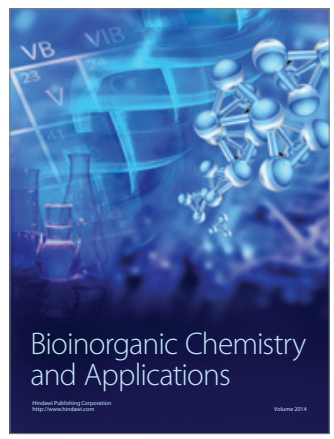

Inorganic Chemistry
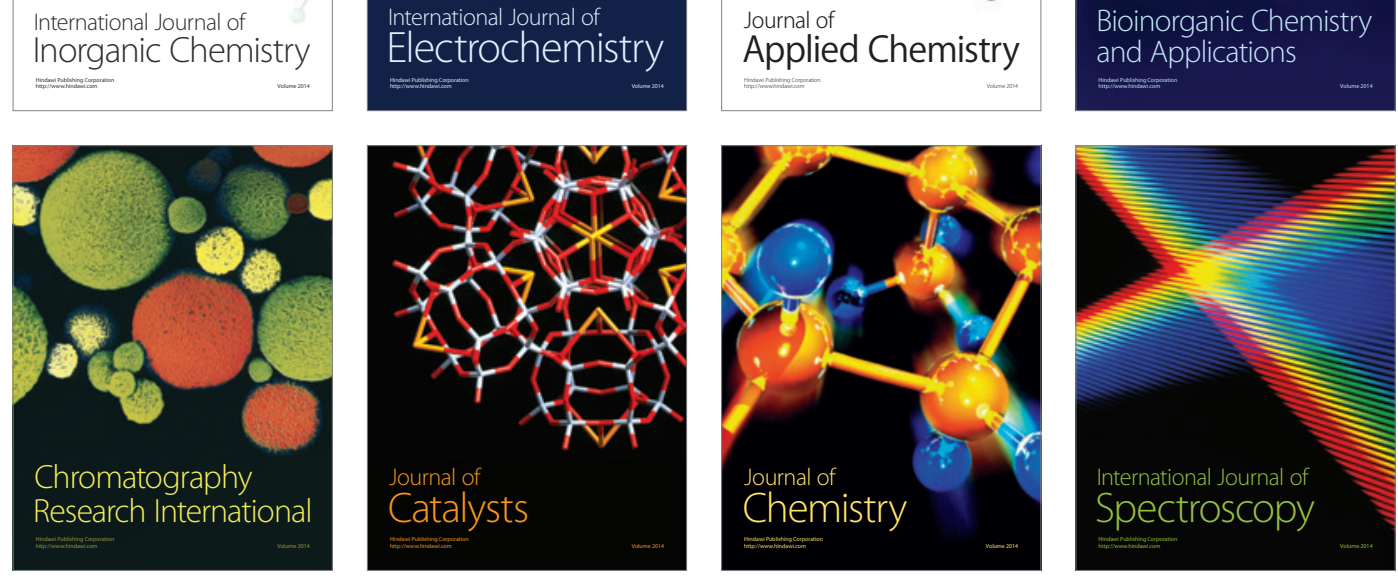